\title{
Analysis of the Conducts of Elite Futsal Goalkeeper in the Different Situations of the Game
}

\author{
A. Paz-Franco ${ }^{1, *}$, A. Bores-Cerezal ${ }^{2}$, R. Barcala-Furelos ${ }^{3}$, M. Mecias-Calvo ${ }^{4}$ \\ ${ }^{1}$ Physical Coach, Al Wahda Futsal, Abu Dhabi, UAE \\ ${ }^{2}$ Physical Coach, Spain National Team, Spain \\ ${ }^{3}$ Special Didactics, University of Vigo, Spain \\ ${ }^{4}$ Physical Coach, Santiago Futsal, Spain \\ *Corresponding author: info@adrianpaz.com
}

Received August 23, 2013; Revised November 01, 2013; Accepted November 05, 2013

\begin{abstract}
The analysis of Futsal goalkeeper acquires great relevance due to the characteristics demanded by the competition that requires its position with respect to the other players and the importance that has this specific position in the game. For this reason we have analyzed the existing interactions between the conducts of the Futsal goalkeeper and different variables (actions, play area, goal-block or error-goal, game situation and team). We have used and observational methodology, because it is one the options of the scientific study of the behavior, as much in real situations as in controlled situations. The results show that in the shots made to the goal, a $76.5 \%$ of them are goalkeeper interventions, in situation of positional attack (54\%), with an incidence in the game on the sidelines areas of the field (L-39\%, R-33\%) and being the technical action more important the cross (33.7\%). Therefore, it is observed relation between the goalkeeper's action and the zone where the opponent shots, between the actions performed by the goalkeeper and the goal (success-block/error-goal), and between the action and the belonging to a specific team. Otherwise, it is not observed relation between goalkeeper's action and the diverse situations of the game.
\end{abstract}

\section{Keywords: indoor soccer, team sports, technique, motor action, training}

Cite This Article: A. Paz-Franco, A. Bores-Cerezal, R. Barcala-Furelos, and M. Mecias-Calvo, "Analysis of the Conducts of Elite Futsal Goalkeeper in the Different Situations of the Game." American Journal of Sports Science and Medicine, vol. 2, no. 3 (2014): 71-76. doi: 10.12691/ajssm-2-3-1.

\section{Introduction}

Futsal is a team sport, that it is characterized by the playful-motor situation of regulated and institutionalized competition, and which it is been from the interactions of cooperation-opposition that occurs between the sportsmen and the means in which they interact (Moreno, 1994).

The elite sport is any organized physical exercise prescribed, in that the training and the competition occupy most of the time and in which the level of exigency is maximum (Coakley, 1983), and that in addition to reach and to maintain the maximum performance, the sportsman uses almost all his time training, which requires physical, mental and social dedication completely (Wylleman, De Knop, Mekenhorst, Theeboom, Annerel, 1993).

The performance in the team sports is the result of the capacity of physical and psychic skills of the different players in its collaboration and also of its capacity of cooperative acting (Konzag, Döber \& Herzog, 1997), developed in conditions of individual and collective fight with the adversaries (Hernández Moreno, 1994; Teodorescu, 1984), in changing surroundings that selectively grant greater or smaller relevance to the conducts of game in the partial and final performance
(Álvaro et al, 1996; Martín Acero, 1993; Seirul-lo, 1993, 1998), with a certain system of game that it is the set of norms that govern the individual, group and collective actions with the objective to obtain the maximum performance of all the equipment and players (Espar, Gerona, 2004).

Martín Acero y Vittori (1997), indicate that without sufficient, multimethodical and coordinated scientific researches that they leave from the necessities of the practice one will not advance in the elaboration of a Theory of the Collective Sport Games. And, therefore, in the validation or negation of the training routines that indeed are able to improve the levels of performance of the sportsmen (Research- Action).

Diverse publications and studies on the reality of the goalkeeper, they try to observe the variables that condition their conduct, as well as the diverse actions they make (Antúnez et al, 2010; LLopis, 2010; Medina et al, 2010; Mulqueen, Woltalla, 2011; Pascual, 2011, Edelman, 2011). Consequently, one becomes necessary to work of specific and individualized way by means of a progression adapted to the referred sport modality, so that we prepare to the goalkeeper for the competition (García, 1997; Hernández Moreno, 2001; Igea, 1997; Medina et al, 2009; Medina et al, 2010).

Like in other collective sports such as soccer, basketball, handball or the hockey, in Futsal the initial positioning of the players is made starting off with specific positions. 
Those positions are a concrete space that each player in the game land occupies, based on the game system that is applied in a while certain of the game (Antón, 1993). We can consider that the specific position of each player varies mainly based on the game system but principally, if the team is in offensive or defensive phase. This does not happen in case of the goalkeeper, who will hold its position and its functions in the defensive phase is referred.

Diverse specialists talk about the Futsal's goalkeeper and its necessary and continued adaptation to make their specific tasks (Bárcenas, 1976; Bárcenas, Román, 1991; Czerwinski, 1993; Paccoud, 1990; Román, 1995), agreeing these authors in equipping with manifest singularity to this figure, accentuated by its dualidad of functions: offensive and defensive, and justified by the importance of its incidence in the outcome of the game.

The fulfillment of the tasks and own exigencies of the specific position of the goalkeeper, is developed in that medium complex and multiform, and are influenced by the circumstantial aspects of the game and the regulation (Antúnez, 2003).

Like in soccer, handball or hockey where the roll of doorman or goalkeeper exists (Sampedro, 1999), the real situation in the most of the games, it will be the last opposing to surpass by the opposite team before obtaining the goal, with the responsibility that it entails. To Palau (2002), the doorman of elite Futsal is a determining factor during the competition, because its performance to a great extent determines the success or the failure of the team. A good preparation, adapted the requirements of the competition, will arrange to the goalkeeper in situation to have greater percentage of success in its interventions.

According to Mutti (2003), the position of the goalkeeper is the most important in Futsal; no other demands that the sportsman is a specialist with respect to their position. This specificity comes marked by its positioning in the field (last player to defend the goal, observes all the game) and for being the only player who has a space of the delimited field where its behavior can be different with respect to the other players. To Fonseca (2001), difference to the goalkeeper of the rest of players because he is the only player with his own characteristics, which make him different from the other members of the team. Mutti (2003), adds that the participation of the goalkeeper in the game in relation to the success (stopped) or error (goal) has a very high incidence and consequently in the performance as much of companions as of adversaries. For that reason he deserves a special consideration and specific training, looking for the purpose of equipping it with the conditions demanded by its position and compatible with its responsibility in the game.

The goalkepeer can be considered in his double function, like the first attacker or the last defender in his collective contribution. In sequence of importance and by the transcendence of its actions, it is possible to be turned in to the most decisive player of all. To Sampedro (1993), the situation, position, the task to develop within the game and, mainly, the regulation, give a differentiating character between the remaining players. This player, as Valdano says (1997), talking about the doorman, it has the audacity to use his hands, in a sport that thinks with the head and it gambles eminently with the foot. As well, the regulation forces the goalkeeper to dress a different color shirt from its companions, adversaries and referees.
The goalkeeper is a specific position that demands special characteristics and, therefore, it must dominate all the facets of the game, own and the pertaining ones to other specific positions, depending on the functions that must fulfill; and that in addition is put under the different interpretations from the regulation, according to its location on the game field.

Therefore, the object of study of the present I articulate has been to analyze the behavior of the goalkeeper of Elite Futsal in the different situations from game, thus to be able to respond to the questions that determine the study object: How influences the diverse variables in the elite doorman? Can condition their conduct before a certain action of the game? Realize always the same motor actions before different situations from the game?

\section{Material and Method}

This study considers from an observational investigation (Figure 1). Having been analyzed the games corresponding to the XXII Futsal Spain King Cup celebrated in Segovia, from February $3^{\text {rd }}$ to February $6^{\text {th }}$ 2011, in where the 8 first teams of the First Division Spain at the end of the first part of the competition have competed: el Barcelona, El Pozo, Interviú, Manacor, Autos Lobelle, Triman Navarra, Benicarló, Caja Segovia, obtaining a sample $(n=16)$ during the course of the competition. The studied variables are: actions of the goalkeeper, team, zone of the field, conditioners and goal.

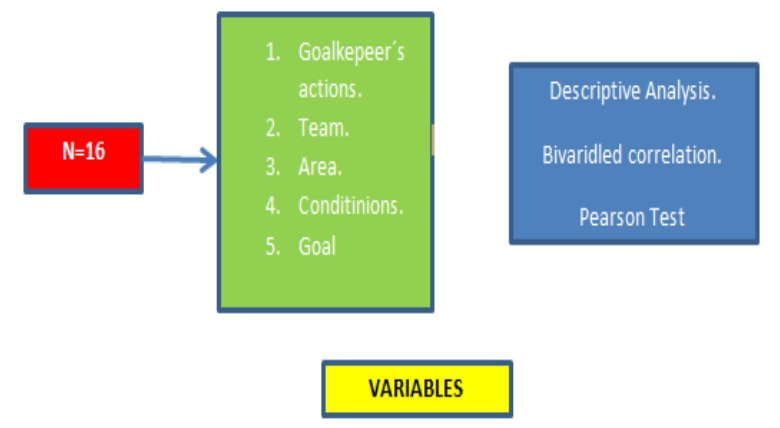

Figure 1. Investigation scheme

For the analysis of the variables has been used software ASTRO Sport Systems, whose purpose is to provide digital support to the Futsal's technicians and players. Actually, it is a common tool used in national teams or to analyze Futsal's great championships.

The procedure used has been divided into three phases. In first place, the captures of the actions required for the investigation were made. In the second phase the captures are analyzed being transferred the observation to a list adhoc that divides the field of game in 8 zones (Figure 2).

The third and last phase supposed the statistical treatment of the data for which the program SPSS 19.0. was used, analyzing the measures of central tendency (average, typical deviation, etc.) and, in a descriptive form, the different selected variables: actions of the Futsal's goalkeeper, zone of the field, conditioners, goals and team. Also, the test of Pearson was created for the analysis between variables, getting the correlation between variables: success, zone, conditions and actions. In order to obtain the results of this last mentioned test between variables, the test of bivaried correlations was used. The level of signification was set at $95 \%$. 


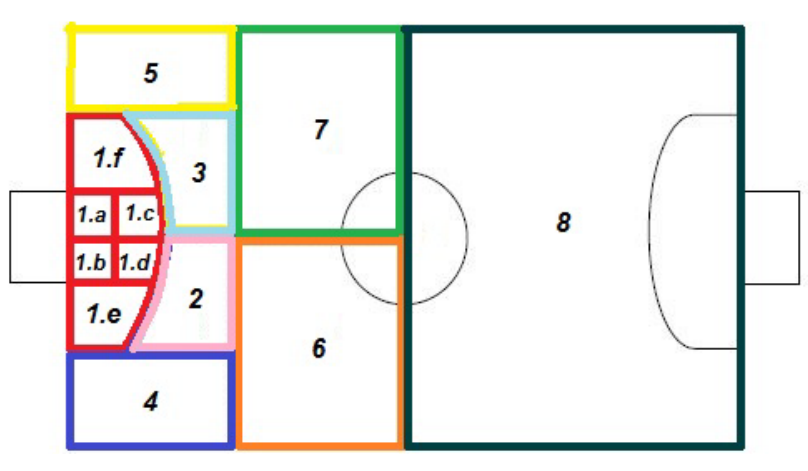

Figure 2. Futsal's field áreas

\section{Results}

We observed the predominant action of the goalkeeper is the cross-foot action (Figure 3), within 17.35\%, followed by the action hand-deviation, within $10.2 \%$. It is observed as most of the results appear in the initial values, range of values pertaining to cross actions (33.7\%) and split (18.9\%), representing a $52.6 \%$ of total actions.
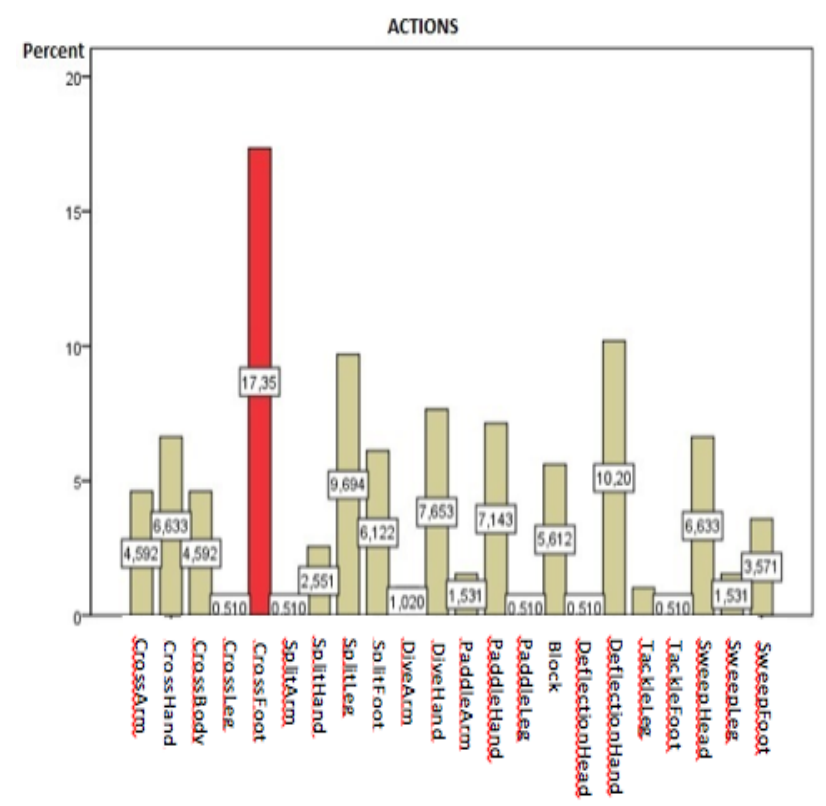

Figure 3. Variable Goalkeeper's actions

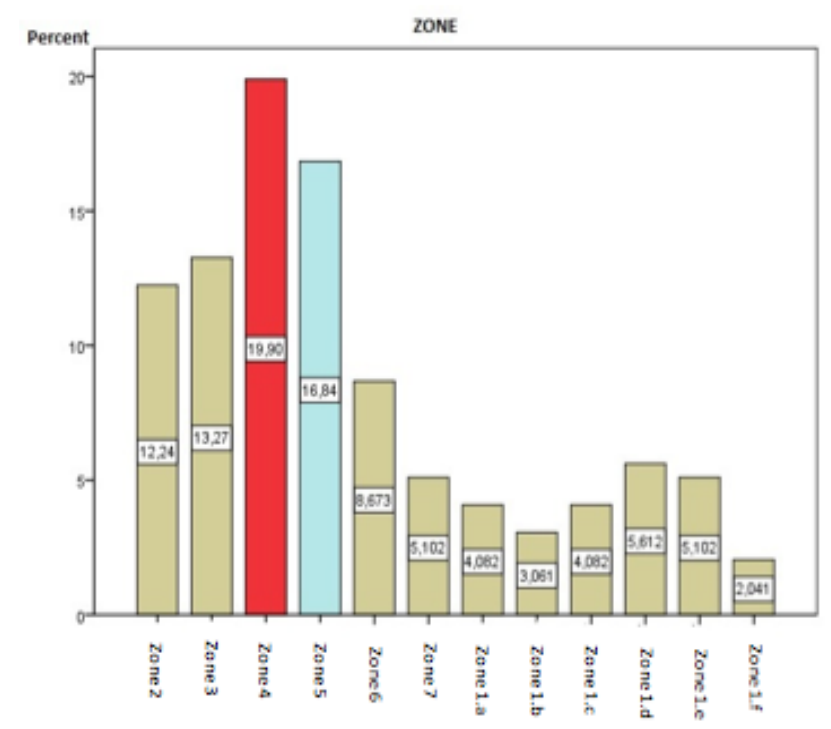

Figure 4. Variable Futsal's field areas
In the frequencies obtained for the zone variable (Figure 4), they emphasize the values obtained for zone 4 (19.9\%) and zone 5 (16.84\%) representing the zones with greater incidence in the game, being these two lateral zones from where the goalkeeper receives the greater amount of shots on goal. If in addition we include the central zones 2 and 3, within $12.24 \%$ and $13.27 \%$ respectively, we obtain a $62.25 \%$ of the shots on goal are made from the adjacent zones to the area, that is to say, from the periphery.

The constraint that is more repeated is the situation of $4 \times 4$ (54.08\%) followed by the situation of $5 \times 4$-known as player-goalkeeper- (7.1\%), being the rest $38.82 \%$ situations of superiorities or inferiorities, both offensives and defensives (Figure 5).

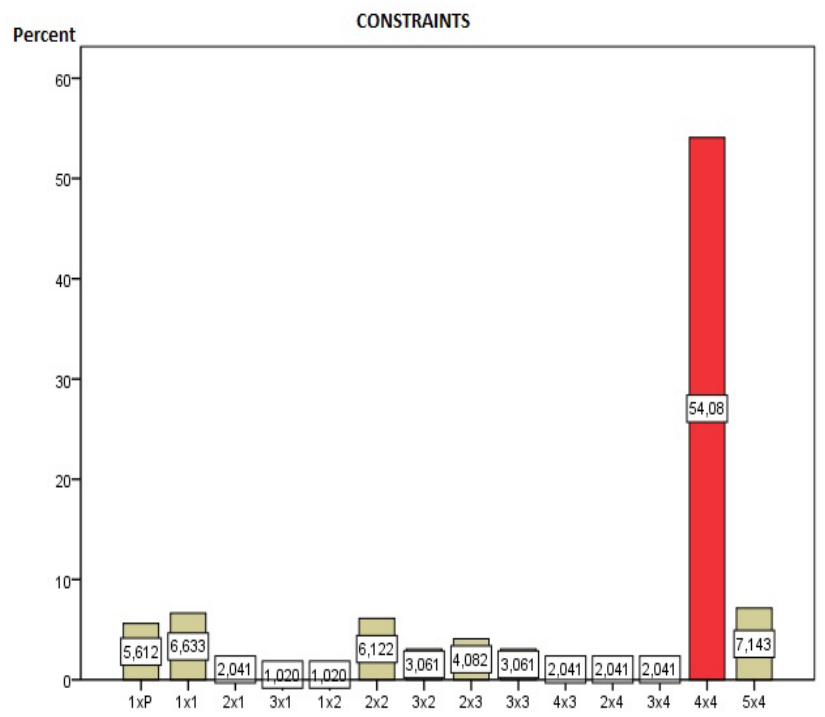

Figure 5. Variable Constraints

In the frequencies obtained for the variable Goals (Success), the save (G0), represents $76.5 \%$ from total of the sample (Figure 6), whereas 23.5\% remaining one shows the conducts of the goalkeeper that finalize in goal, being the zones G1, G3 and G9 (Figure 7) those that respectively represent a greater index of getting a goal on the part of the adversary with a $4.5 \%$ each one of the zones, with respect to $23.5 \%$ total.

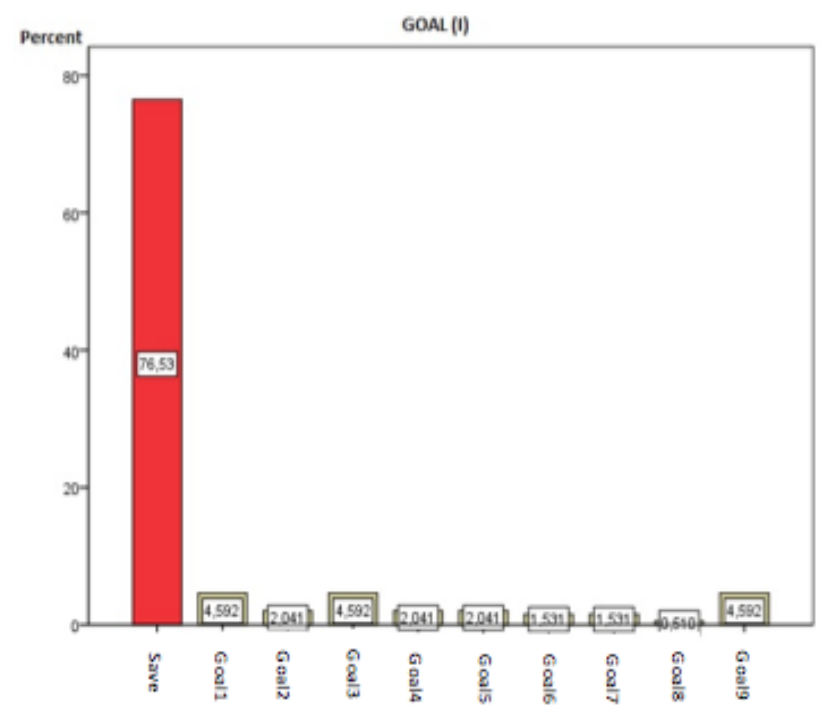

Figure 6. Variable Goals (I) 
The fitted Goals represent 23.5\% of the total of the interventions of the doorman, in who many of the actions are erroneous (Figure 7). In the erroneous actions, there are 3 zones of goal that have greater incidence as far as the reception of a goal: Goal Zone 1, Goal Zone 3 and Goal Zone 9 , with a $4.5 \%$ respectively, that it supposes $13.5 \%$ on $23.5 \%$ of the total of fitted goals.

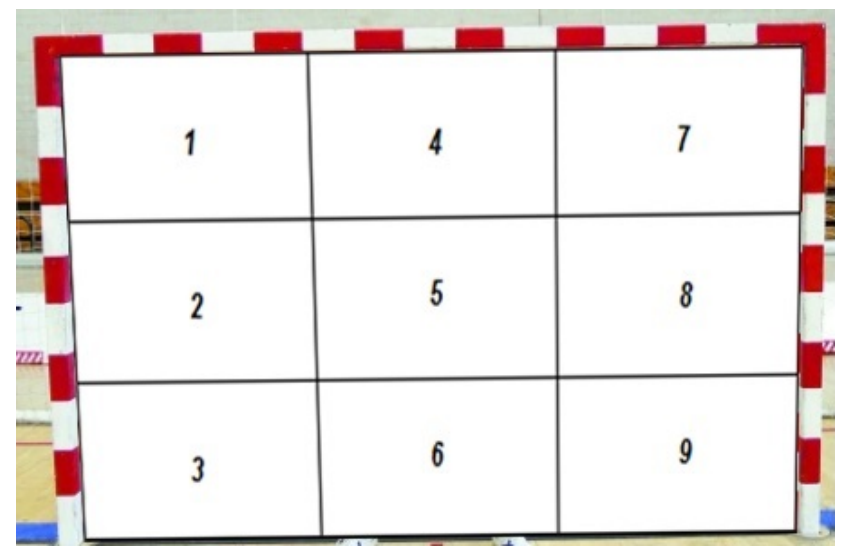

Figure 7. Variable Goals (II)

At sight of the obtained results we have made a statistical analysis between the different variables, with the objective to observe the existing relation between the same ones, determining which relations exist between the variable "Actions" and the rest of variables: Zone, Goal and Team. The level of signification has been set to ( $\mathrm{p}=$ $0.004),(p=0.010)$ and $(p=0.001)$ respectively, observaing that the action to perfom by the goalkeeper has a close relation with the Zone where the opponent is shooting, what will determine a certain motor action or another one, in the same way that an incorrect action of the goalkeeper is going to be negative for its team: the Goal. It is observed in the same way, as the property to a determined Team influences in the motor action to make by the Futsal's goalkeeper.

By contrast, it is not observed a relation between the variables Actions and Constraints $(p=0.786)$, that is to say, the game situations that occur previous to any shot on goal $(4 \times 4,3 \times 2,2 \times 1 \ldots)$ they do not influence in the motor action of the goalkeeper.

\section{Discussion}

In order to know the real potential of productivity of the sportsman, it is necessary to relate it to the demands in the official games with competitive perspective, because these will be the indicators to program later training.

Van Lingen (1999), states that if one is just allowing players to run or to increase "gymnasium" training to fortify itself, then the only thing that will be obtained is to reinforce the muscle to carry out all those movements. Therefore, the factors that we must analyze and consider in a training planning are those that the player demands, according to its technical-tactical and psychological work to do during the competition. Nevertheless, another percentage to increase the performance must, by the direct influence that it has, to the sport diet, the social situation and the system of daily civic-sport life of the player. Being the situations ignored and not contemplated in the planning, and that are insofar determining for the performance. The tendency of the training system has to have an integral character taking into account the sportsman from a holistic perspective, leaving back the analytic scheme and being this decompensated (to separate technical aspect from the physical and psychological ones).

Seiru-lo (2000), maintains that the separation of body and mind no longer exists, the human being must be educated and trained as a unique process of optimization of the sportsman. When training a team, the planning is born from the individual, that is to say, according to its function and capacity it faces various game actions requiring different answers each time, as it happens in a competitive match. By automating excessively exercises are working only a portion of the athlete, both cognitively and physically. It can be valuable in psycho motor sports, but not in social motor sports.

Futsal, as a team sport provides many complex situations which pose a major challenge in terms of decision-making (Greháigne, Godbout, Bouthier, 2001). Motor skills that occur in team sports are characterized, principally, because the necessity to adapt to changing environment where they develop. Therefore, in performing this type of work, besides the technical component of motor performance, it is required by the player to employ tactical conducts that enable him to give competent performance in each stage of the game (Thomas, Thomas, 1994). Team sports involve, essentially, a series of sequences and game situations that are added to every moment, making it difficult to get an identical reproduction (Ruiz, 1994). That is why, these sports require from the player, additionally unlike individual sports, cognitive activities of perception and decision making.

In 1963, Barbara Knapp says that skill in team sports is determined by technique and decision making, understanding the technique as the ability to carry out the motor component of the action, and decision making as knowledge to choose the right technique based on the particular situation where the action is playing.

Cognitive components include knowledge and decision making, while the skill component would correspond to motor execution (Iglesias, Ramos, Fuentes, Sanz, Del Villar, 2003). Therefore, the quality of decision-making in a game situation is as important as the execution of motor skills, both being crucial to athletic performance (Thomas, 1994; Blomqvist, Luhtanen, Laakso, 2001).

The formation and maintenance of an elite athlete should be complete, avoiding as much as possible not to leave anything to chance. As we ascend to the next levels of sport's requirement, this increases the variables to be controlled and requires an increasingly scientific and technological support. These factors of performance indicate that the elite goalkeeper's profile is fitted perfectly to this profile of performance, being capable to be investigated.

Comparing the results with those of similar studies, we observed that from all of the observed actions, a 76.5\%, were successful, while a $23.5 \%$ of the motor actions finished in Goal (Figure 6). Martín Rascón (2009), reflects in his study similar results to those obtained here, being $74 \%$ of motor actions successful and $26 \%$ of motor actions that ended in a goal.

Regarding to shooting zones, the results show a higher incidence in the lateral zones, 4 and 5 (Figure 2), with 
19,9\% and 16,84\% (Figure 4) respectively of the total, while Martín Rascón (2009) highlights the central area (47\%) as the highest, in terms of incidence.

By contrast, the results obtained by Ferreira (1998), are similar to ours, emphasizing the lateral areas, with $22 \%$ and $16 \%$ respectively, as the areas of greatest impact on the game.

For areas where the goalkeeper receives more goals, are G1, G3 y G9 with 19.25\% respectively each (Figure 7), coinciding zones G3 y G9 with the results obtained by Martín Rascón (2009) in his study, in which further emphasizes as incident area, the right side of the goal, with $52 \%$ of total incidence, which considered a problem because most of the porters are right-handed.

\section{Conclusions}

The game situations before a shot on goal do not determine motor action to be performed by the Futsal goalkeeper. Regardless of the game situation (3x2, 4x4, $2 \times 2$, etc.) their are other variables that will affect their motor action. The first is belonging to a particular team. The existence of diverse methodologies combined with the idea that each professional athlete has in their area of work can cause training differences in respect to different clubs.

By contrast, motor actions are closely related to the firing on goal, since it determines that the performance by the goalkeeper in one or another way. We can say that even without driving action types exist in each area, if there are predominant motor actions in each of the same.

They, also, will determine the success or failure of launches to the rivals goal, determining largely the outcome of the action. Since the proper execution of a specific motor action and the correct choice of the same for any given game situation, will the futsal goalkeeper ready to make a save (success) in that game situation, assuming an erroneous choosing a goal against.

Sampedro (1997) says that "the keeper error as last player is hardly remediable by a teammate".

\section{References}

[1] Abernethy, B. (1996). Training the visual-perceptual skills of athletes. The American Journal of Sports Medicine, 24, 89-92.

[2] Abernethy, B., Kippers, V., Mackinnon, L. T., Neal, N. J., y Harharan, S. J. (1997). The Biophysical Foundations of Human Movement. Champain, IL., Human Kinetics, pp. 295-311.

[3] Álvaro, J.; Dorado, A.; González Badillo, JJ.; González, J.L.; Navarro, F.; Molina, JJ.; Portolés, J.; Sánchez, F. (1996). Modelo de análisis de los deportes colectivos basado en el rendimiento en competición, INFOCOES, 7, 21-41.

[4] Anguera, M.T., Blanco, A., Losada, J.L., Hernández Mendo, A. (2000): La metodología observacional en el deporte: conceptos básicos. Lecturas: Educación Física y Deportes, 5 (24). (http//www.efdeportes.com/efd24/obs.htm).

[5] Antón, J. L. (1993). Hacia una lógica conceptual en Balonmano. Ponencia presentada en Congreso Internacional de Especialistas en Balonmano. Madrid.

[6] Antúnez, A. (2003). La interceptación en la portera de balonmano: efectos de un programa de entrenamiento perceptivo-motriz. Madrid: C.V. Ciencias del Deporte.

[7] Antúnez, A., García, M. M., Argudo, F. M., Ruiz, E., \& Arias, J. L. (2010). Resultado de un programa de entrenamiento perceptivomotor sobre la eficacia en competición de la portera de balonmano según la oposición del lanzador. / result of a perceptive-motor trining program on the efficacy in competition from handball female goalkeeper according to the thrower opposition. Revista Kronos, 9(17), 29-37.

[8] Barbero Álvarez JC, D'Ottavio S, Granda Vera J, Castagna C. (2009). Aerobic fitness in futsal players of different competitive level. J Strength Cond, Res 23: 2163-6.

[9] Bárcenas, D. (1976). Técnica. Madrid: Federación Española de Balonmano.

[10] Bárcenas, D. y Román, J. D. (1991). Balonmano: Técnica y Metodología. Madrid: Gymnos.

[11] Blomqvist, M., Luhtanen, P., y Laakso, L. (2001). Comparison of two types of instruction in badminton. European Journal of Physical Education, 6, 139-155.

[12] Casáis Martínez, Luis. Rey Eiras, Ezquiel. Apuntes de Fundamentos de los Deportes Colectivos I: Balonmano. 2012, Facultad de las Ciencias de la educación y del deporte, Universidad de Vigo.

[13] Coakley, J. (1983). Leaving Competitive Sport: Retirement or Rebirth?, Human Kinetics Journals, QUEST volume 35, Issue 1, February.

[14] Czerwinski, J. (1993). El Balonmano, técnica, táctica y entrenamiento. Barcelona: Paidotribo.

[15] Dellal A, Hil-Haas S, Lago-Penas C, Chamari K. Small-sided games in soccer: amateur vs. professional players' physiological responses, physical, and technical activities. J Strength Cond Res 2011; 25: 2371-81.

[16] Edelman, B. (2011). The goalkeeper. Directed by S. Timoshenko, screenplay by Lev Kassil. USSR: Lenfilm, 1936 Bob Edelman Soccer \& Society, 1743-9590, Volume 12, Issue 1, 2011, Pages 42-43.

[17] Espar y Gerona (2004). Elementos para el diseño de tareas del entrenamiento en los deportes de equipo, Master Profesional en Alto Rendimiento en Deportes de Equipo. Área Coordinativa, Barcelona. Byomedic - Fundació F.C. Barcelona.

[18] Ferreira, P. (1998). "Caracterização da finalização em equipas de Futsal”. UNICAMP (SP), 1998.

[19] Fonseca, G.M.M. (2001). Futsal - treinamento para goleiros 2. ed. Rio de Janeiro: Editora Sprint Ltda, 2001

[20] García, A. R. (1997). Análisis de los gestos técnicos y acciones del juego en fútbol sala recurso electrónico (Versión 1.0 ed.). Madrid Gymnos, D.L. 1997: Gymnos.

[21] González Víllora, S., Gutiérrez, D., Pastor, C., Fernández, J. (2007). Análisis funcional de los deportes de invasión: importancia del subsistema técnico-táctico en el juego. Concreción en el Fútbol. Retos. Nuevas tendencias en educación física, deporte y recreación. 2007, nº12, pp18-28.

[22] Gréhaigne, J. F., Godbout, P., y Bouthier, D. (2001). The teaching and learning of decision making in team sports. Quest, 53, 59-76.

[23] Hernández Moreno, J. (2001). Análisis de los parámetros espacio y tiempo en el fútbol sala. la distancia recorrida, el ritmo y dirección del desplazamiento del jugador durante un encuentro de competición: Los casos de J. gay (defensa), C. marrero (cierre), J. beto (pivote), J. limones (ala) y J. clavería (portero). Apunts.Educación Física y Deportes, (65), 33-44.

[24] Hernández Moreno, J. (1994): Análisis de las estructuras del juego deportivo. Fundamentos del deporte, Barcelona: INDE.

[25] Igea, J. M., \& Durán, R. (1997). El portero en el fútbol sala. Madrid Gymnos, 1997: Gymnos.

[26] Iglesias, D., Ramos, L. A., Fuentes, J. P., Sanz, D., y Del Villar, F. (2003). El conocimiento y la toma de decisiones en los deportes de equipo: una revisión desde la perspectiva cognitiva. Revista de Entrenamiento Deportivo, 17, 2, 5-11.

[27] Knapp, B. H. (1963). Skill in sport: the attainment of proficiency. Routledge and Kegan Paul, London.

[28] Konzag, I.; Döbler, H.; Herzog, H-D. (1997). Entrenarse jugando, Barcelona. Paidotribo.

[29] Lago Peñas, Carlos. Apuntes de Fundamentos de los Deportes Colectivos I: Fútbol. 2011, Facultad de Ciencias de la educación y deporte, Universidad de Vigo.

[30] LLopis, L. (2010). Implicación y relación del portero en el juego colectivo. Madrid 2010: Revista ABFUTBOL.

[31] Makaje N, Ruangthai R, Arkarapanthu A, Yoopat P. (2012). Physiological demands and activity profiles during futsal match play according to competitive level. J Sports Med Phys Fitness, 52(4):366-74.

[32] Martín Acero, R. (1993). Velocidad y velocidad en deportes de equipo, Colección CadernosTécnico-Pedagóxicos do INEF de Galicia, A Coruña. Centro Galego de Documentación e Edicións Deportivas. 
[33] Martín Acero, R; Vittori, C. (1997). Metodología del rendimiento deportivo (I): Sentido, definición y objeto de estudio, Revista de Entrenamiento Deportivo, XI, 1, 5-10.

[34] Martín Rascón, J. (2009). ¿Dónde radica el error del gol en Fútbol Sala? Análisis del portero. Revista Internacional de Deportes Colectivos. 2, 36-57.

[35] Milanez VF, Pedro RE, Moreira A, Boullosa DA, Salle-Neto F, Nakamura FY. (2011). The Role of Aerobic Fitness on Session Rating of Perceived Exertion in Futsal Players. Int J Sports Physiol Perform, 6; 358-66.

[36] Medina, A. A., del, M. G., Iturriaga, F. M. A., Lara, E. R., \& Artero, J. L. A. (2009). Efecto de un programa de entrenamiento perceptivo-motor sobre la eficacia global de la portera de balonmano en Competición. / effect of a perceptive-motor training program on the global efficacy from handball female goalkeeper in competition. / efeito de um programa de treinamento perceptivo-motor sobre a eficacia global da golera de handbol na CompetiÇao. Cuadernos De Psicología Del Deporte, 9(2), 31-43.

[37] Medina, A. A., del, M. G., Iturriaga, F. M. A., Lara, E. R., \& Artero, J. L. A. (2010). Entrenamiento perceptivo en la portera de balonmano ante la trayectoria del tiro. Revista Internacional De Medicina y Ciencias De La Actividad Física y Del Deporte, nº37.

[38] Moreno, J.H. (1994). Fundamentos del deporte. Analisis de las estructuras del juego desportivo. 1.ed. Barcelona: Inde Publicaciones, 1994.

[39] Mulqueen, T., Woltalla, M. (2011). The Complete Soccer Goalkeeper: Techniques and Tactics for Stopping Every Shot. Soccer Journal May/Jun2011, Vol. 56 Issue 3, p54 2p.

[40] Mutti, D. (2003). Futsal: da iniciação ao alto nível. 2 ed. São Paulo: Phorte, 2003.

[41] Paccoud, B. (1990). L' entrainement du gardien de but. EPS, 40, 39-42.

[42] Palau, X. (2002) Apuntes de Preparación física aplicada al fútbol sala. Curso de $2^{\circ}$ nivel de Entrenadores. Centro de Alto Rendimiento de Sant Cugat, Barcelona.

[43] Pascual, J. (2011). Manual técnico del portero de fútbol. Barcelona 2011: Paidotribo.

[44] Román, J. D. (1995). El portero. En Real Federación Española de Balonmano (Ed.), Clinics Deportes de Base y de Entrenadores de Élite, (pp. 15-16). Madrid: RFEBM.
[45] Ruiz, L. M. (1994). Deporte y aprendizaje. Procesos de adquisición y desarrollo de habilidades. Madrid: Visor.

[46] Ruiz-Risueño, J., De la Cruz Sanchez, E. (2008). El papel del entrenador en la capacidad decisional de los jugadores. Retos. Nuevas tendencias en Educación Física, Deporte y Recreación. 2008, $\mathrm{n}^{\circ} 13$, pp. 5-10.

[47] Sampedro, J. (1993). Iniciación al Fútbol Sala. Madrid 1993: Gymnos.

[48] Sampedro, J. (1997). "Análisis praxiológico de los deportes de equipo: una aplicación al futbol sala”. Director: José Hernández Moreno. Universidad Politécnica de Madrid, 1997.

[49] Sampedro, J. (1999). Fundamentos de táctica deportiva. Análisis de la estrategia de los deportes. Madrid: Gymnos.

[50] Seirul-lo, F. (1993). Planificación del entrenamiento en deportes de equipo, Master en Alto Redimiento Deportivo. Módulo 2.1.7., Madrid. C.O.E.-Universidad Autónoma de Madrid.

[51] Seirulo, F. (1998). Preparación física en deportes de equipo, Curso de Postgrado en Preparación Física, A Coruña, no publicado.

[52] Seirul.lo, F. (2000) Una línea de trabajo distinta. I Jornadas de Actualización de Preparadores Físicos, COE, 5 de Junio.

[53] Teodorescu, L. (1984). Problemas de teoria e metodogia nos jogos desportivos, Lisboa. Livros Horizonte.

[54] Thomas, K. T. (1994). The development of sport expertise: From Leeds to MVP legend. Quest, 46, 211-222.

[55] Valdano, J. (1997). Los cuadernos de Valdano. Madrid. El PaisAguilar.

[56] Van Lingen, Bert. (1999) Captación de talentos en holanda. Nazioarteko futbol elkaraldiak. Editorial Bizkaiko Foru Aldundia, Bizkaia, 155-165.

[57] Vera, G., Pino, J., Romero, C., Moreno, I. (2007). Propuesta de valoración técnico-táctica mediante una situación de juego colectivo básico en el fútbol de iniciación. Retos. Nuevas tendencias en Educación Física, Deporte y Recreación. 2007, n¹2, pp. 29-35.

[58] Wylleman, P., De Knop, P., Menkehorst, H., Theeboom, M., y Annerel, J. (1993). Career termination and social integration among elite athletes. In S. Serpa, J. Alves, V. Ferreira, \& A. Paula-Brito (Eds.), Proceedings of the VIII World Congress of Sport Psychology (pp. 902-906). Lisbon: International Society of Sport Psychology. 